\title{
Mars Ascent Vehicle Design for Human Exploration
}

\author{
Tara Polsgrove ${ }^{1}$, Dan Thomas ${ }^{2}$, Steven Sutherlin ${ }^{2}$, and Walter Stephens ${ }^{3}$ \\ National Aeronautics and Space Administration, George C. Marshall Space Flight Center, Huntsville, AL, 35812 \\ and \\ Michelle Rucker ${ }^{4}$ \\ National Aeronautics and Space Administration, Lyndon B. Johnson Space Center, Houston, TX, 77058
}

In NASA's evolvable Mars campaign, transportation architectures for human missions to Mars rely on a combination of solar electric propulsion and chemical propulsion systems. Minimizing the Mars ascent vehicle (MAV) mass is critical in reducing the overall lander mass and also eases the requirements placed on the transportation stages. This paper presents the results of a conceptual design study to obtain a minimal MAV configuration, including subsystem designs and mass summaries.

\section{Nomenclature}

$\begin{array}{ll}A R V & =\text { Asteroid Redirect Vehicle } \\ B O L & =\text { Beginning of life } \\ C B E & =\text { Current Best Estimate } \\ \mathrm{DOI} & =\text { Descent Orbit Insertion } \\ E C L S & =\text { Environmental Control and Life Support } \\ E V A & =\text { Extravehicular Activity } \\ F A S & =\text { Flight Analysis Software } \\ I S R U & =\text { In-Situ Resource Utilization } \\ I V A & =\text { Intravehicular Activity } \\ \mathrm{Isp} & =\text { engine specific impulse } \\ K & =\text { Kelvin } \\ k g & =\text { kilogram } \\ k N & =\text { kilonewton } \\ \mathrm{kPa} & =\text { kilopascals } \\ k W & =\text { kilowatt } \\ L C H & =\text { Liquid methane } \\ L C I & =\text { Layered Composite Insulation } \\ L E A & =\text { Launch, Entry, and Abort } \\ L O X & =\text { Liquid Oxygen } \\ L T P & =\text { Launch Targeting Processor } \\ m & =\text { meter } \\ m^{2} & =\text { square meters } \\ m^{3} & =\text { cubic meters } \\ M A G & =\text { Maximum Absorbency Garment } \\ M A V & =\text { Mars Ascent Vehicle } \\ M D M & =\text { Mars Descent Module } \\ M L I & =\text { Multi-Layer Insulation } \\ \mathrm{MOI} & =\text { Mars Orbit Insertion } \\ & \end{array}$

\footnotetext{
${ }^{1}$ Human architectures team lead, Flight Programs and Partnerships Office, Mail Stop FP30.

${ }^{2}$ Engineer, Engineering Directorate, Mail Stop ED04.

${ }^{3}$ Engineer, Flight Programs and Partnerships Office, Mail Stop FP30.

${ }^{4}$ Engineer, Exploration Integration and Science Directorate, Mail Stop XM.
} 


$\begin{array}{ll}M P a & =\text { Megapascals } \\ M P S & =\text { Main Propulsion System } \\ N D S & =\text { NASA Docking System } \\ O M P & =\text { Orbital Maneuvering Processor } \\ p s i & =\text { pounds per square inch } \\ P O S T & =\text { Program to Optimize Space Trajectories } \\ R C S & =\text { Reaction Control System } \\ S E P & =\text { Solar Electric Propulsion } \\ S L S & =\text { Space Launch System } \\ \text { sol } & =\text { Mars solar day } \\ t & =\text { metric ton } \\ T C S & =\text { Thermal Control System } \\ \text { TEI } & =\text { Trans-Earth Injection } \\ V & =\text { Volt } \\ V J & =\text { Vacuum Jackets } \\ V M E & =\text { Versa Module Europa } \\ W & =\text { Watt } \\ W M S & =\text { Waste Management System }\end{array}$

\section{Introduction}

$\mathrm{T}$ HE NASA Human Spaceflight Architectures Team is currently studying an Evolvable Mars Campaign ${ }^{1}$ that $^{2}$ aims to define an evolutionary path from current spaceflight infrastructure and capabilities to the ultimate goal of landing people on the surface of Mars and returning them to Earth. The Mars ascent vehicle (MAV) design has a significant effect on the Mars transportation architecture. Changes in MAV mass estimates ripple back through the architecture, affecting the entry and descent stage design of the lander as well as the performance for Earth launch and transportation to Mars.

Preliminary analyses early in 2014 indicated that the minimum Mars lander mass capable of supporting human missions was $43 \mathrm{t}$ at Mars entry. This minimum mass was determined by the single largest indivisible payload element required for the surface mission, the Mars ascent vehicle. At that time, the MAV (along with the ISRU plant, small rover and tunnel) was estimated to be $18 \mathrm{t}$ delivered to the surface and $40 \mathrm{t}$ fully loaded with liquid oxygen gathered from the Martian atmosphere. Transportation studies at that time indicated that a solar electric propulsion (SEP) vehicle derived from the Asteroid Redirect Vehicle (ARV), and limited to $150 \mathrm{~kW}$ beginning of life (BOL) power generation, could deliver $40 \mathrm{t}$ to Mars orbit ${ }^{2,3}$. With a potential $3 \mathrm{t}$ gap in performance needed for delivering Mars landers, effort began to further refine the SEP trajectory and performance analysis to increase performance and further refine Mars lander mass estimates.

In the fall of 2014, a conceptual design study was initiated to refine mass estimates for a Mars ascent vehicle capable of lifting 4 astronauts off the surface of Mars. Results of that study are presented in this paper including operations and functional requirements, configuration, and mass properties as well as subsystem design and vehicle performance sensitivities.

\section{Operations}

The MAV's primary objective is to lift crew and cargo off the surface of Mars and dock with an orbiting MarsEarth transportation vehicle. The MAV (without the oxygen propellant) is predeployed years in advance of a crew landing to allow adequate time for propellant generation. The MAV uses oxygen that is collected and liquefied on the Martian surface along with methane brought from Earth as propellant.

Transit time from Earth launch to arrival in Mars orbit ranges between 300 days and 1400 days depending on the transportation system used. Purely SEP systems take the longest when power limited to $150 \mathrm{~kW}$, while purely chemical transportation systems follow minimum energy trajectories which are much shorter in duration than those involving SEP propulsion. Hybrid SEP/chemical systems fall between that range ${ }^{4,5}$. The baseline assumed for this study is an SEP transit with flight times given in Figure 1. During transit, the MAV relies on the descent stage of the lander for power, communications, and thermal control.

Shortly after arrival into a $250 \mathrm{~km}$ x 33,800 km Mars orbit, commonly referred to as a 1 sol orbit, the lander carrying the MAV detaches from the Earth-Mars transportation system. After a brief period of final checkouts and phasing to align with the targeted landing site, the lander descends to the surface. Once on the surface the lander must be connected to a surface power generator, currently assumed to be a fission power source that is delivered 
with the MAV or on an earlier lander. Connection to surface power is assumed to occur within 24 hours after landing. Surface power is required for liquid oxygen production and to prevent boiloff of the ascent propellants. Oxygen production rates are dependent on available power, but the production duration is expected to be up to one year. During surface operations the MAV relies on the descent stage for communications, thermal control, and connection to surface power.

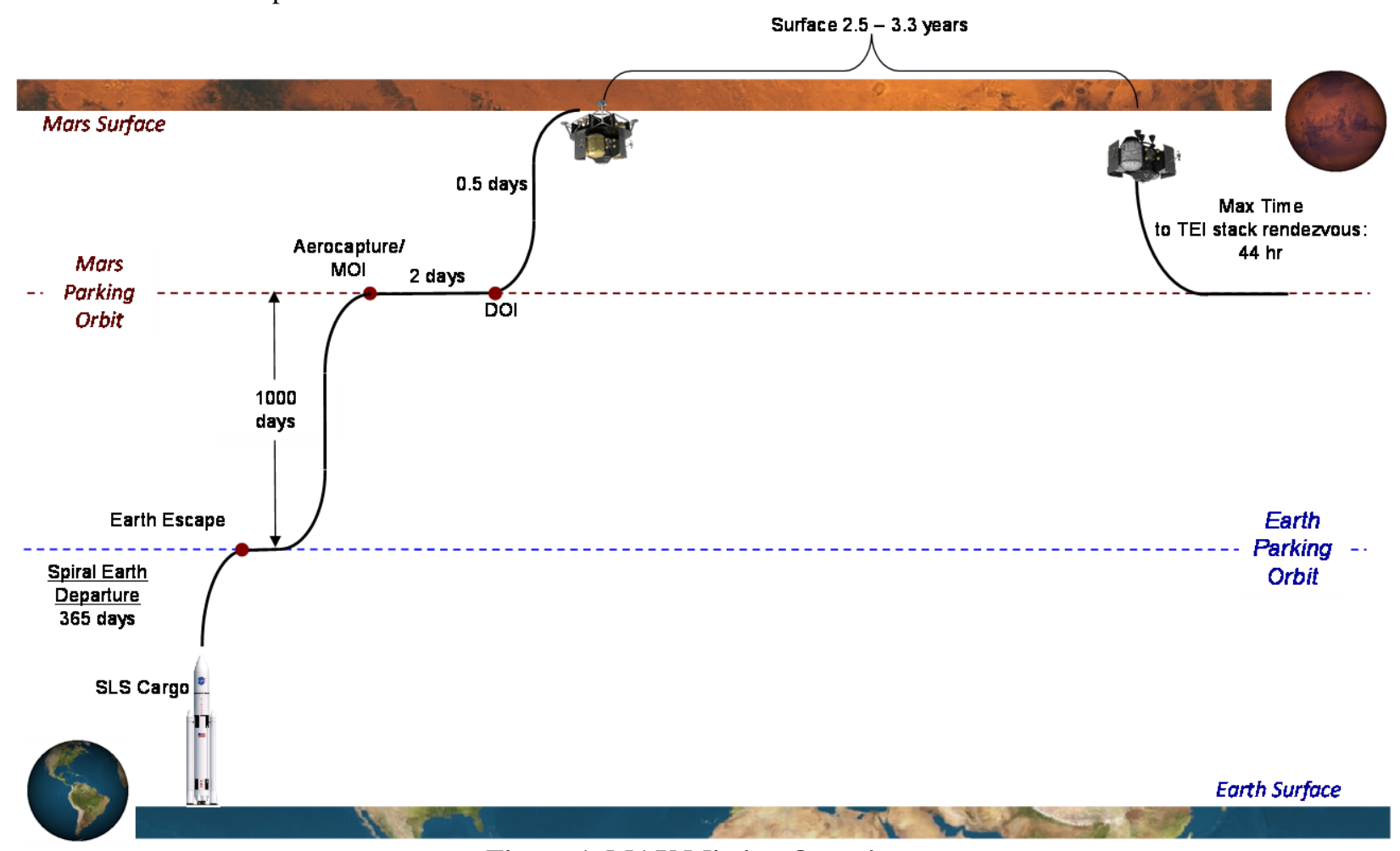

Figure 1. MAV Mission Overview.

To minimize requirements on the MAV, as well as mass and complexity, crew access is limited during the surface missions to brief periods of checkout operation before ascent ${ }^{6}$. The MAV is not intended to be a secondary habitat, though it is capable of sheltering the crew for a limited period of time in an emergency situation. Nominal crew access begins the day before launch. Two crew members travel to the MAV from their surface habitat via pressurized rover and perform system checkout operations and stow cargo in the MAV. The remaining crew members arrive the day of the launch. Crew ingress is facilitated by a pressurized tunnel connected to the rover. The tunnel minimizes the potential to contaminate the MAV with martian soil which would become airborn once the MAV reached orbit. It also allows the crew to leave surface exploration suits behind in the rover and enter the MAV and ascend in the lighter and more flexible launch and entry suits. One key assumption is that the crew remain in their suits with visors up during ascent through rendezvous and dock except for brief hygiene breaks. This minimizes the "feed the leak" duration and consumables penalty in the event of a cabin leak and minimizes required cabin size by eliminating the need to store 4 empty suits.

Just prior to ascent all support services from the descent stage are discontinued, and the MAV becomes selfsufficient. A powered ascent leaves the MAV in a $100 \times 250 \mathrm{~km}$ altitude orbit. The MAV then circularizes into a $250 \mathrm{~km}$ orbit and awaits optimum phasing for rendezvous with the Earth return vehicle (in the 1 sol parking orbit). Once docking is achieved and crew and cargo are transferred, the MAV detaches and performs a final disposal maneuver into an orbit that will not interfere with future Mars orbit operations.

\section{Vehicle Overview}

\section{A. Configuration}

The MAV is a two-stage vehicle with three $100 \mathrm{kN}$ engines on the first stage and a single engine (same thrust) on the second stage. The first stage consists of only a main propulsion system (MPS) with two sets of nested tanks, for liquid oxygen and liquid methane. These components are dropped after the first stage burn, leaving the second stage which contains the cabin, crew, propulsion system (MPS and RCS), along with the supporting subsystems, 
including fixed thermal radiators (wrapped around the second stage tanks) and the fuel-cell power generation system. Like the first stage, the second stage has two sets of nested propellant tanks. Figure 2 shows both stages and packaging in a 10-m diameter SLS fairing, while Figure 3 displays only the second stage. The MAV height is $5.8 \mathrm{~m}$ with a cabin diameter of $2.7 \mathrm{~m}$, which provides an internal volume of $17.5 \mathrm{~m}^{3}$. Two hatches allow for entry from the Mars surface and docking to the Earth return vehicle. The NASA docking system ${ }^{7}$ is assumed for the top hatch, and a 40 inch rectangular hatch is assumed on the side. Figure 4 shows the MAV on the surface connected to the rover via pressurized tunnel. This arrangement of cabin and propulsion system components allows for relatively straightforward crew access as well as a low center of gravity for the overall lander, which is desired for controlability during the entry, descent and landing phases.

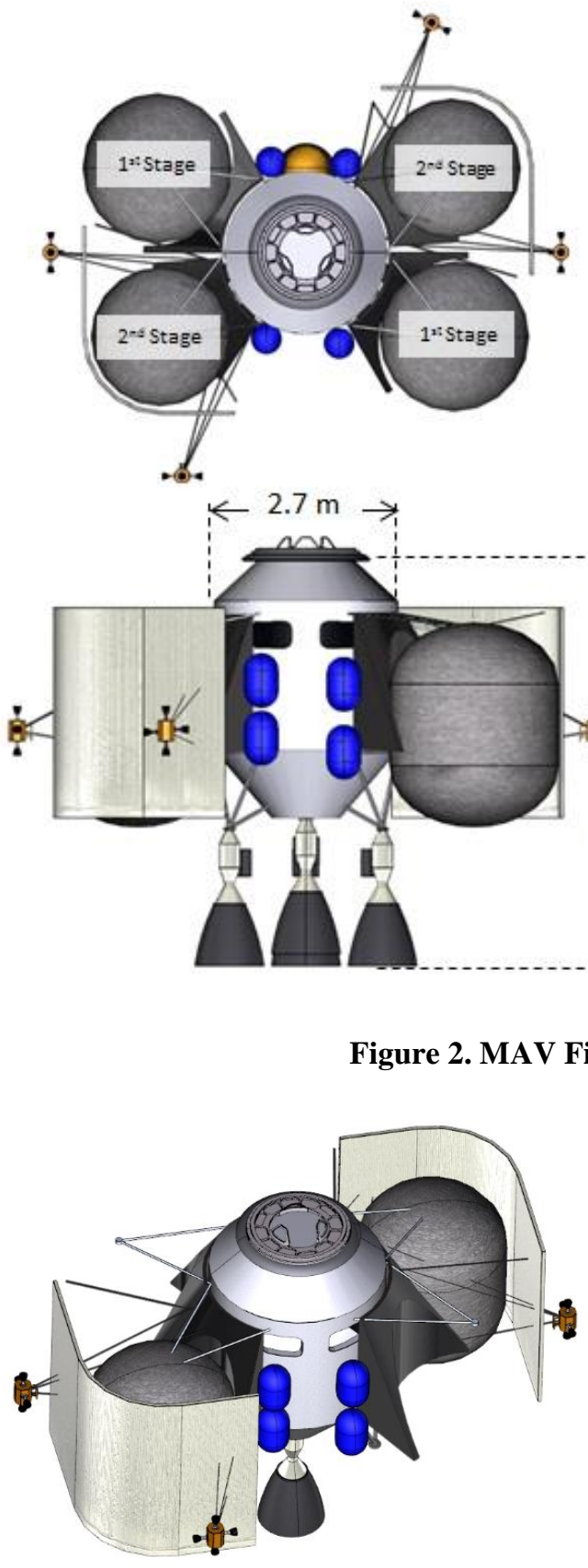

Figure 3. MAV Second Stage.
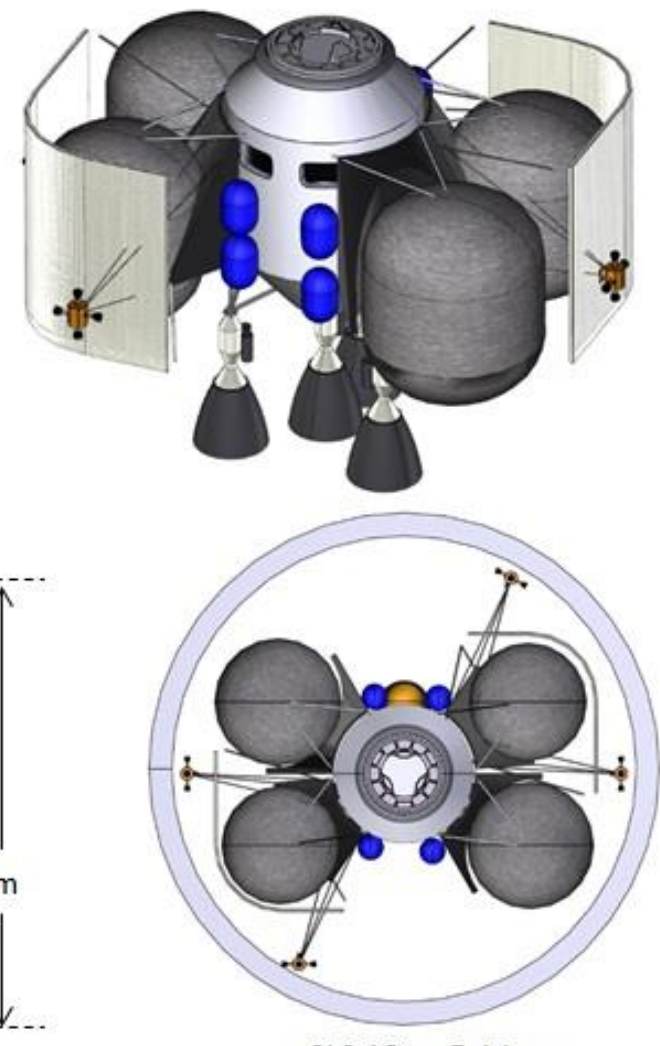

SLS 10-m Fairing

Figure 2. MAV First and Second Stages.

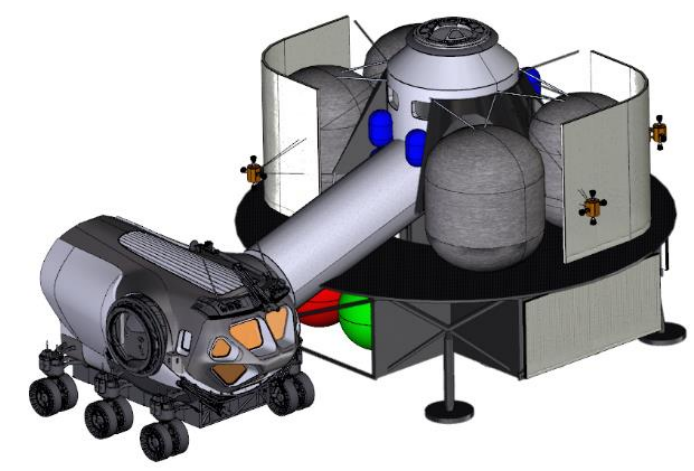

Figure 4. Crew Access Tunnel to MAV.

4

American Institute of Aeronautics and Astronautics 
Figure 5 shows the nested tank information for both stages. Each first stage tank contain fuel and oxidizer masses of $2,298 \mathrm{~kg}$ and 7,841 kg, respectively. This gives a total first stage propellant load of $20.3 \mathrm{t}$. The second stage tank is slightly smaller and contains $1191 \mathrm{~kg}$ of $\mathrm{LCH}_{4}$ and $3523 \mathrm{~kg}$ of LOX, giving a combined propellant load of $9.4 \mathrm{t}$ for both tanks.
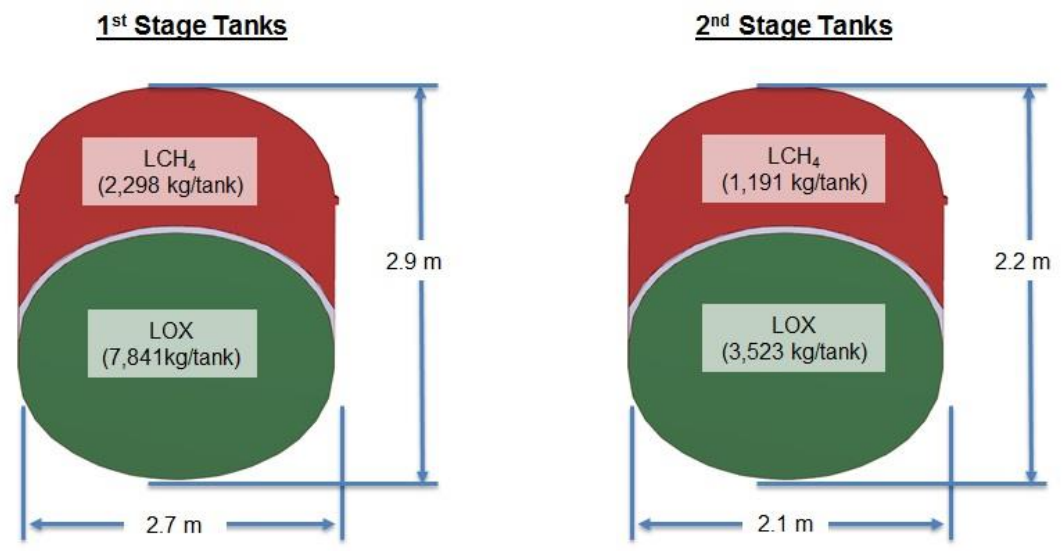

Figure 5. Nested Tank Information.

\section{B. Vehicle Mass Properties}

The MAV subsystem masses, including the totals, are shown in Table 1. The total MAV mass at the beginning of the crewed ascent is $39.1 \mathrm{t}$, which consists of a $3.8 \mathrm{t}$ crew cabin, $23.5 \mathrm{t}$ first stage, and $11.8 \mathrm{t}$ second stage. The listed propellants represent the total loaded masses, which contain 19.4 t of usable propellant on the first stage and 8.7 $\mathrm{t}$ on the second stage. Note: all propulsion items (including engines and tanks) are part of the dry masses of the first and second stages.

The total mass at Earth departure is $15.7 \mathrm{t}$. The MAV is launched without liquid oxygen, which will be provided on the Martian surface by the lander ISRU system. Also absent are the return cargo, crew, and their space suits.

\section{Vehicle Overview}

\section{A. Trajectory}

The ascent performance of the MAV was modeled using Program to Optimize Space Trajectories (POST). The flight originates from $30^{\circ}$ north latitude and ends in the initial low Mars orbit of $100 \mathrm{~km}$ x $250 \mathrm{~km}$ with a $30^{\circ}$ inclination. Three engines are used for the first stage, producing a liftoff acceleration of 0.78 Earth g's. Staging occurs at 225.8 seconds with a maximum acceleration of 1.52 Earth g's. The single second stage engine burns for 192.6 seconds to insertion into the low Mars orbit. Maximum acceleration during this burn is 1.10 Earth g's.
Table 1. MAV Masses.

\begin{tabular}{|r|r|r|}
\hline \multirow{2}{*}{ Subsystem } & \multicolumn{2}{|c|}{ Mass (kg) } \\
\cline { 2 - 3 } & Earth Departure & Mars Liftoff \\
\hline Crew Cabin & $\mathbf{3 , 1 5 1}$ & $\mathbf{3 , 8 4 6}$ \\
\hline Structures & 858 & 858 \\
\hline Power & 377 & 377 \\
\hline Avionics & 407 & 407 \\
\hline Thermal & 542 & 542 \\
\hline ECLS & 298 & 298 \\
\hline Cargo & 411 & 1,106 \\
\hline Non-Prop. Fluids & 258 & 258 \\
\hline 1st Stage & $\mathbf{7 , 7 9 1}$ & $\mathbf{2 3 , 4 7 3}$ \\
\hline Dry Mass & 3,195 & 3,195 \\
\hline LOX & 0 & 15,681 \\
\hline LCH4 & 4,597 & 4,597 \\
\hline 2nd Stage & $\mathbf{4 , 7 1 9}$ & $\mathbf{1 1 , 7 5 6}$ \\
\hline Dry Mass & 2,378 & 2,378 \\
\hline LOX & 0 & 7,036 \\
\hline LCH4 & 2,341 & 2,341 \\
\hline Total Masses: & $\mathbf{1 5 , 6 6 2}$ & $\mathbf{3 9}, \mathbf{0 7 5}$ \\
\hline
\end{tabular}

These stage burn durations are optimized by POST based on the input propellant mass fractions of the stages.

The MAV then starts the sequence of burns using either the main engine of the 2nd stage or RCS, whichever is appropriate for the burn, to rendezvous with the Trans-Earth Habitat in a 1 sol orbit. The rendezvous analysis was performed by Jeffrey Gutkowski, NASA Johnson Space Center, using Flight Analysis Software (FAS) specifically the Launch Targeting Processor (LTP) and Orbital Maneuvering Processor (OMP). The results are shown in Fig. 6. The maximum acceleration during this phase of the mission is about $1.4 \mathrm{~g}$ 's and occurs at the end of the "Coelliptic" maneuver (the only main engine burn after the $100 \mathrm{~km}$ x $250 \mathrm{~km}$ insertion). 


\begin{tabular}{|l|c|c|c|}
\hline & $\begin{array}{c}\text { Hp } / \mathbf{H a} \\
\mathbf{( k m )}\end{array}$ & $\begin{array}{c}\Delta \mathbf{V} \\
(\mathbf{m} / \mathbf{s})\end{array}$ & $\begin{array}{c}\text { Time } \\
\text { From } \\
\text { Launch } \\
\text { (hh:mm) }\end{array}$ \\
\hline 1. Raise periapsis & $166 / 250$ & 15 & $00: 57$ \\
\hline 2. Phasing & $162 / 471$ & 50 & $01: 51$ \\
\hline 3. Height & $200 / 470$ & 8 & $04: 43$ \\
\hline 4. Coelliptic (NSR) & $200 / 33,792$ & 1147 & $24: 50$ \\
\hline 5. Lambert-targeted (TPI) & $240 / 33,762$ & 4.6 & $34: 50$ \\
\hline 6. Braking Maneuver (TPF) & $250 / 33,796$ & 1.7 & $43: 55$ \\
\hline
\end{tabular}

- Incorporated within the $\Delta V$ numbers above the

- Out-of-plane contribution was $4 \mathrm{~m} / \mathrm{s}$

- Radial contribution was $4 \mathrm{~m} / \mathrm{s}$

- Therefore the majority of the total $\Delta \mathbf{V}$ comes from in-plane $\Delta \mathbf{V}$, indicating that each maneuver is performed at its respective optimal location

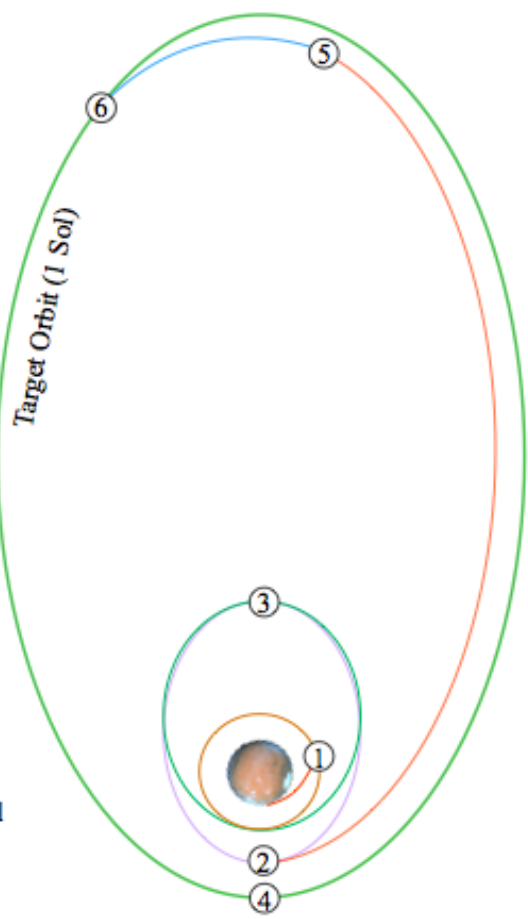

Figure 6. Phasing and Rendezvous

Shorter flight durations from the surface to rendezvous with the Earth return vehicle are possible. The option presented here allows for multiple launch opportunities per day every day during the surface mission assuming the Earth return vehicle is positioned appropriately for a co-planar ascent. Reducing flight duration affects the launch window availability and required $\Delta \mathrm{V}$. For a difference of only 3 additional $\mathrm{m} / \mathrm{s}$ of $\Delta \mathrm{V}$, a 24 hour flight to 1 sol can be achieved, but this trajectory solution may only be available a few days out of each month. A 12 hour flight could be possible with an additional $190 \mathrm{~m} / \mathrm{s}$ of $\Delta \mathrm{V}$, but the opportunities are likely to be even less frequent, and the launch windows may only be minutes long. For this MAV design, propellant loads are calculated assuming the slightly higher $\Delta \mathrm{V}$ for a 24 hour flight, and the crew consumables are computed for the 44 hour flight. This allows a one day ascent if conditions permit, while protecting for a longer flight if needed.

\section{B. Aerodynamics}

The atmospheric pressure on the surface of Mars is only about $0.6 \%$ of Earth's sea level pressure and drops off quickly with altitude, however the effect on ascent vehicle performance cannot be neglected. The drag coefficients used in the POST simulation are shown in Fig. 7 and represent a preliminary assessment of the MAV aerodynamics. FUN3D (Fully Unstructured Navier-Stokes) is used in the analysis with an 8-species Mars atmosphere composition (nonreacting) and the MAV configuration models. The assumed reference length and area are $5.13 \mathrm{~m}$ and $22.06 \mathrm{~m}^{2}$, respectively. The displayed coefficients are for a zero angle of

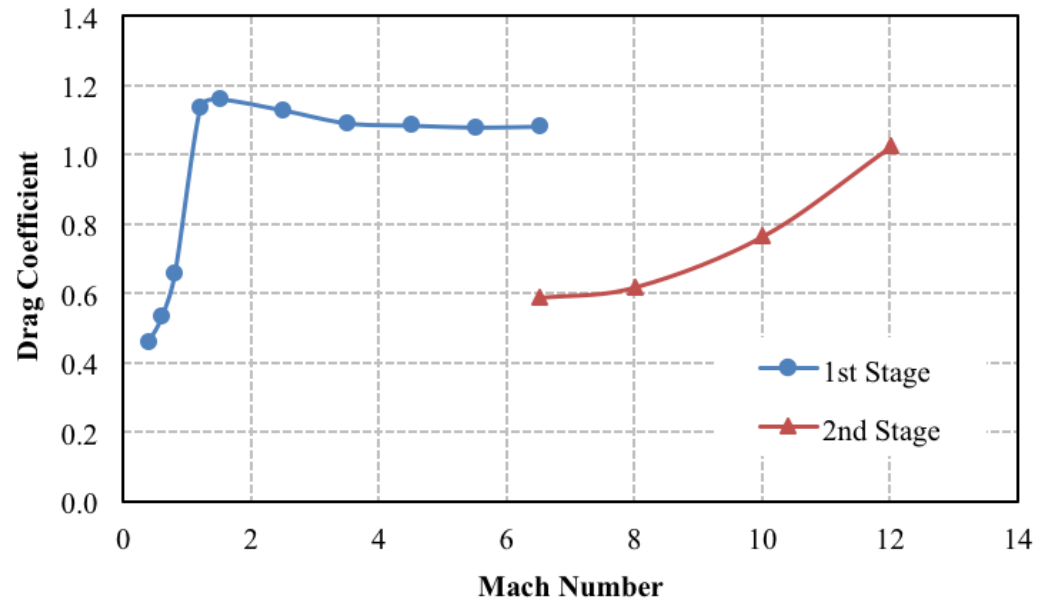

Figure 7. MAV Drag Coefficients. attack. 


\section{Comparison to Apollo and Altair Lunar Ascent Vehicles}

The Apollo Lunar Module ascent stage is the only vehicle that has carried humans off the surface of another planetary body. Over six missions these vehicles carried a total of 12 astronauts and $382 \mathrm{~kg}$ of samples off the surface of the moon to rendezvous and dock with the orbiting command module. The Altair lunar lander (part of NASA's Constellation Program that was cancelled in 2010) was to have a larger and more capable ascent module. It was designed to carry 4 crew members instead of 2 and a higher allocation for the return of lunar samples on each ascent. While the Altair ascent module never flew, with three years of significant design effort and two years of formulation prior to that, it is the highest fidelity design of an ascent vehicle since the Apollo Lunar Module. In comparison, the Mars Ascent Vehicle is significantly more massive than both lunar ascent vehicles. This is primarily due to the very different propulsion requirements of the Mars vs. Lunar ascent trajectories ${ }^{8}$. Table 2 provides a comparison of requirements and masses.

Table 2. Comparison to Apollo and Altair Ascent Vehicles.

\begin{tabular}{|l|c|c|c|}
\hline & Apollo & Altair & MAV \\
\hline Number of Crew & 2 & 4 & 4 \\
\hline Crew Cabin Pressurized Volume $\left(\mathrm{m}^{3}\right)$ & 6.65 & $\begin{array}{c}17.5 \\
\text { (including airlock) }\end{array}$ & 17.5 \\
\hline Ascent to Docking Flight Time $(\mathrm{hrs})$ & $2.1-3.7$ & 2.5 & $24-44$ \\
\hline Ascent $\Delta \mathrm{V}(\mathrm{m} / \mathrm{s})$ & 1,900 & 1,985 & 5,274 \\
\hline Dry Mass $(\mathrm{kg})$ & 1,901 & 2,615 & 9,419 \\
\hline Propellant Mass $(\mathrm{kg})$ & 2,492 & 3,147 & 29,655 \\
\hline Total Mass $(\mathrm{kg})$ & 4,795 & 6,190 & 39,075 \\
\hline
\end{tabular}

\section{Vehicle Systems}

\section{A. Propulsion}

The MAV propulsion system is separated into two stages. The first stage contains three $100 \mathrm{kN}$ engines that consume liquid oxygen (oxidizer) and liquid methane (fuel). The engine operates at a specific impulse of $360 \mathrm{~s}$ and a propellant oxidizer-to-fuel mixture ratio of 3.5. The second stage contains a single main engine (same engine as first stage) along with four banks of four (16 total) reaction control engines. Each RCS engine produces $445 \mathrm{~N}$ of thrust and a specific impulse of $340 \mathrm{~s}$. The corresponding mixture ratio is 3.0. The first stage MPS pulls propellant from two nested tanks on that stage (see Figure 4 above). The second stage tanks provide propellants to both the MPS and RCS engines. RCS propellants must be vaporized and then pumped into accumulator tanks before usage. Gaseous propellants allow high pulse rates during attitude control. The maximum pressure in the accumulator tanks is 27.6 MPa. The gas-fed engine assumption proved to be complex and resulted in a high power requirement. Therefore, liquid-fed RCS engines will be studied for future design iterations.

The tank pressures are maintained at $345 \mathrm{kPa}$. The LOX is pressurized with helium, stored in ambient bottles at $31 \mathrm{MPa}$. Each bottle has a blowdown ratio of 3.0, and the process is assumed to be isentropic. The LCH4 tank pressurization is autogenous. Cryocoolers maintain the propellant temperatures to prevent boiloff. The liquid oxygen is kept at $94 \mathrm{~K}$, while the liquid methane is stored at $112 \mathrm{~K}$. Other assumptions include a $5 \%$ ullage volume for each propellant, $1 \%$ residual propellants, and a $1 \%$ fuel bias. All propulsion masses are listed in Tables 3 and 4 for the first and second stages, respectively. 
Table 3 First Stage Propulsion Masses.

\begin{tabular}{|c|c|c|c|c|c|c|}
\hline System & Item & Qty & $\begin{array}{c}\text { Unit Mass } \\
(\mathrm{kg})\end{array}$ & $\begin{array}{c}\text { Basic Mass } \\
(\mathrm{kg})\end{array}$ & $\begin{array}{c}\text { Growth } \\
(\%)\end{array}$ & $\begin{array}{c}\text { CBE Mass } \\
(\mathrm{kg})\end{array}$ \\
\hline \multicolumn{7}{|c|}{ Dry Mass } \\
\hline \multirow[t]{9}{*}{ MPS } & & & & 2347 & 25 & 2933 \\
\hline & Main Engine & 3 & 181 & 544 & 25 & 680 \\
\hline & Oxidizer Subsystem & 1 & 127 & 127 & 25 & 158 \\
\hline & Fuel Subsystem & 1 & 135 & 135 & 25 & 168 \\
\hline & Pressurization \& Pneumatics & 1 & 199 & 199 & 25 & 248 \\
\hline & Mounting Hardware & 1 & 100 & 100 & 25 & 126 \\
\hline & Nested Tanks & 2 & 300 & 600 & 25 & 750 \\
\hline & MPS Tank Cryocoolers/BAC & 1 & 44 & 44 & 25 & 55 \\
\hline & MPS Tank Insulation & 1 & 598 & 598 & 25 & 748 \\
\hline \multicolumn{7}{|c|}{ Non-Propelled Fluids } \\
\hline \multirow[t]{3}{*}{ Residuals } & & & & & & 664 \\
\hline & Oxidizer & & & & & 479 \\
\hline & Fuel & & & & & 185 \\
\hline \multirow[t]{2}{*}{ Fuel Bias } & & & & & & 43 \\
\hline & Fuel & & & & & 43 \\
\hline \multirow[t]{3}{*}{ Reserves } & & & & & & 194 \\
\hline & Oxidizer & & & & & 151 \\
\hline & Fuel & & & & & 43 \\
\hline \multirow[t]{3}{*}{ Pressurant } & & & & & & 58 \\
\hline & Gaseous Helium & & & & & 32 \\
\hline & Autogenous Fuel & & & & & 25 \\
\hline \multicolumn{7}{|c|}{ Used Propellant } \\
\hline \multirow[t]{3}{*}{ Mnvr Prop } & & & & & & 19,267 \\
\hline & Oxidizer & & & & & 14,986 \\
\hline & Fuel & & & & & 4,282 \\
\hline \multirow[t]{3}{*}{ Engine Start/Stop } & & & & & & 85 \\
\hline & Oxidizer & & & & & 66 \\
\hline & Fuel & & & & & 19 \\
\hline
\end{tabular}


Table 4. Second Stage Propulsion Masses.

\begin{tabular}{|c|c|c|c|c|c|c|}
\hline System & Item & Qty & $\begin{array}{c}\text { Unit Mass } \\
(\mathrm{kg})\end{array}$ & $\begin{array}{c}\text { Basic Mass } \\
(\mathrm{kg})\end{array}$ & $\begin{array}{c}\text { Growth } \\
(\%)\end{array}$ & $\begin{array}{c}\text { CBE Mass } \\
(\mathrm{kg})\end{array}$ \\
\hline \multicolumn{7}{|c|}{ Dry Mass } \\
\hline \multirow[t]{10}{*}{$M P S$} & & & & 1247 & 25 & 1559 \\
\hline & Main Engine & 1 & 181 & 181 & 25 & 227 \\
\hline & Oxidizer Subsystem & 1 & 50 & 50 & 25 & 62 \\
\hline & Fuel Subsystem & 1 & 51 & 51 & 25 & 64 \\
\hline & Pressurization \& Pneumatics & 1 & 143 & 143 & 25 & 178 \\
\hline & Mounting Hardware & 1 & 43 & 43 & 25 & 53 \\
\hline & Nested Tanks & 2 & 138 & 276 & 25 & 345 \\
\hline & MPS Tank Cryocoolers/BAC & 1 & 98 & 98 & 25 & 123 \\
\hline & MPS Tank Insulation & 1 & 370 & 370 & 25 & 463 \\
\hline & Radiators & 1 & 36 & 36 & 25 & 44 \\
\hline \multirow[t]{9}{*}{$R C S$} & & & & 561 & 20.45 & 676 \\
\hline & Heating & 1 & 17 & 17 & 25 & 21 \\
\hline & Heat Exchanger & 1 & 10 & 10 & 25 & 13 \\
\hline & High Pressure Storage & 1 & 54 & 54 & 25 & 68 \\
\hline & Lines \& Hardware & 1 & 50 & 50 & 18 & 59 \\
\hline & Propellant Distribution & 1 & 116 & 116 & 17 & 136 \\
\hline & RCS Engine POD (4 engines) & 4 & 72 & 287 & 21 & 347 \\
\hline & Thermal Control & 1 & 18 & 18 & 23 & 23 \\
\hline & Instrumentation & 1 & 9 & 9 & 16 & 10 \\
\hline \multicolumn{7}{|c|}{ Non-Propelled Fluids } \\
\hline \multirow[t]{3}{*}{ Residuals } & & & & & & 231 \\
\hline & Oxidizer & & & & & 169 \\
\hline & Fuel & & & & & 62 \\
\hline \multirow[t]{2}{*}{ Fuel Bias } & & & & & & 41 \\
\hline & Fuel & & & & & 41 \\
\hline \multirow[t]{3}{*}{ Reserves } & & & & & & 87 \\
\hline & Oxidizer & & & & & 67 \\
\hline & Fuel & & & & & 19 \\
\hline \multirow[t]{3}{*}{ Pressurant } & & & & & & 23 \\
\hline & Gaseous Helium & & & & & 17 \\
\hline & Autogenous Fuel & & & & & 6 \\
\hline \multicolumn{7}{|c|}{ Used Propellant } \\
\hline \multirow[t]{3}{*}{ Mnvr Prop } & & & & & & 8,622 \\
\hline & Oxidizer & & & & & 6,689 \\
\hline & Fuel & & & & & 1,933 \\
\hline Engine Start/Stop & & & & & & 57 \\
\hline & Oxidizer & & & & & 44 \\
\hline & Fuel & & & & & 13 \\
\hline
\end{tabular}

\section{B. Structures}

A detailed finite element analysis is performed to estimate the MAV structures. The model is shown Figure 8, which also includes the driving assumptions. The results are listed in Table 5. The propellant tanks are estimated in a similar manner (given above in Tables 3 and 4). Micrometeoroid/orbital debris shielding is not included. Further study on exposure risk and required shielding is needed. 


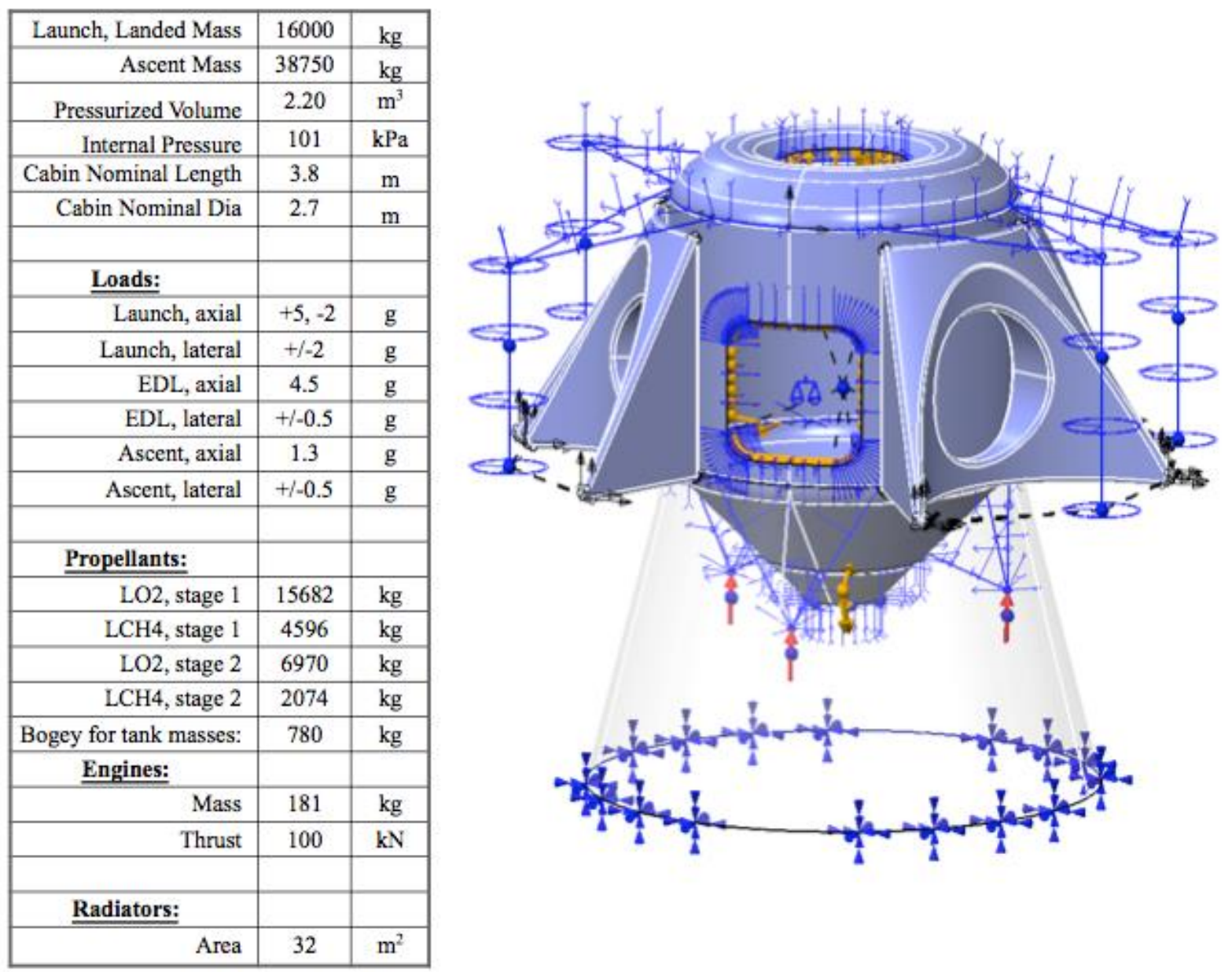

Figure 8. Structures Finite Element Module and Assumptions. 
Table 5. First and Second Stage Structures Masses.

\begin{tabular}{|c|c|c|c|c|c|c|}
\hline System & Item & Qty & $\begin{array}{c}\text { Unit Mass } \\
(\mathrm{kg})\end{array}$ & $\begin{array}{c}\text { Basic Mass } \\
(\mathrm{kg})\end{array}$ & $\begin{array}{c}\text { Growth } \\
(\%)\end{array}$ & $\begin{array}{c}\text { CBE Mass } \\
(\mathrm{kg})\end{array}$ \\
\hline \multicolumn{7}{|c|}{ First Stage } \\
\hline Tank Support & & & & 163 & 25 & 204 \\
\hline & Sandwich Panel Assemblies & 2 & 76 & 152 & 25 & 189 \\
\hline & Strut Assemblies & 2 & 6 & 12 & 25 & 14 \\
\hline Thrust Structure & & & & 20 & 25 & 25 \\
\hline & Strut Assemblies & 3 & 7 & 20 & 25 & 25 \\
\hline \multicolumn{7}{|c|}{ Second Stage } \\
\hline Cabin & & & & 686 & 25 & 858 \\
\hline & Composite Sandwich Shell & 1 & 237 & 237 & 25 & 297 \\
\hline & Upper \& Lower Ring Frame & 1 & 21 & 21 & 25 & 26 \\
\hline & Hatch Frame & 1 & 11 & 11 & 25 & 14 \\
\hline & Floor & 1 & 50 & 50 & 25 & 63 \\
\hline & Side Hatch & 1 & 100 & 100 & 25 & 125 \\
\hline & Top Hatch (NDS Passive Side) & 1 & 92 & 92 & 25 & 115 \\
\hline & Window Assemblies & 2 & 23 & 45 & 25 & 56 \\
\hline & Secondary Structure & 1 & 68 & 68 & 25 & 85 \\
\hline & Descent Module Interface & 1 & 40 & 40 & 25 & 50 \\
\hline & Engine Support Structure & 1 & 22 & 22 & 25 & 28 \\
\hline Thrust Structure & & & & 101 & 25 & 126 \\
\hline & Sandwich Panel Assemblies & 2 & 45 & 90 & 25 & 112 \\
\hline & Strut Assemblies & 2 & 6 & 11 & 25 & 14 \\
\hline
\end{tabular}

\section{Power}

The maximum power required for MAV operation is estimated at $10 \mathrm{~kW}$. The power generation system consists of three solid oxide fuel cell power plants, each producing $5 \mathrm{~kW}$. This allows for maximum MAV power usage to be carried by two fuel cells with one fuel cell held in reserve. The fuel cells draw $\mathrm{CH} 4$ and $\mathrm{O} 2$ from the second stage propellant tanks. Solid oxide cells are used due to their higher power densities and efficiencies. The reactant amounts are computed based on a $60 \%$ fuel cell efficiency with an applied margin of $20 \%$. This technology is currently being developed at NASA Glenn Research Center.

The power management distribution system consists of MPCV-based boards housed in a rugged, space qualified VME enclosure. Cabling is based on Altair cable lengths but are resized for a $120 \mathrm{~V}$ bus and a $2 \%$ line losses. All power elements (masses shown in Table 6) are placed on the second stage.

Table 6. Power Subsystem Masses.

\begin{tabular}{|c|c|c|c|c|c|}
\hline Item & Qty & $\begin{array}{c}\text { Unit Mass } \\
(\mathrm{kg})\end{array}$ & $\begin{array}{c}\text { Basic Mass } \\
(\mathrm{kg})\end{array}$ & $\begin{array}{c}\text { Growth } \\
(\%)\end{array}$ & $\begin{array}{c}\text { CBE Mass } \\
(\mathrm{kg})\end{array}$ \\
\hline \multicolumn{6}{|c|}{ Dry Mass } \\
\hline Power System & & & 283 & 33 & 377 \\
\hline Fuel Cell & 3 & 41 & 123 & 25 & 154 \\
\hline Power Distribution Unit & 2 & 32 & 64 & 25 & 80 \\
\hline Reactant Feed Lines & 1 & 4 & 4 & 25 & 5 \\
\hline Cabling \& Connectors & 1 & 92 & 92 & 50 & 138 \\
\hline \multicolumn{6}{|c|}{ Non-Propelled Fluids } \\
\hline Fuel Cell Reactants & & & 278 & 20 & 333 \\
\hline $\mathrm{O} 2$ & & & 56 & 20 & 67 \\
\hline CH4 & & & 222 & 20 & 267 \\
\hline
\end{tabular}




\section{Thermal}

The MAV Thermal Control Subsystem (TCS) performs three main functions: (1) mitigate heat loads and losses due to spacecraft interaction with the environment; (2) provide heat rejection for MAV subsystems such as Avionics, Power, ECLS, Human Factors (including crew metabolic heat), and Thermal Control; and (3) provide propellant conditioning for the MAV propulsion system during flight and surface storage. The TCS must operate in a wide range of thermal conditions, such as the diurnal Mars surface environment with its warm and cold extremes, the fairly benign Earth elliptical orbit, and the rather cold Mars orbit/transit environments.

The MAV TCS is composed of insulation systems, heaters and thermal coatings to moderate heating rates to and from the environment. Fluid systems, such as pumped coolant loops and cryocoolers with broad area cooling tubing networks, are included to perform heat collection. Loop heat pipe radiators are used to reject heat to the environment. Cryocooler and loop heat pipe technologies are currently not at a mature state of readiness. Fault tolerance for TCS elements is provided at the component level for such things as rotating equipment, valves and sensors.

MAV insulation systems, heaters, and thermal coatings are used to mitigate the impact of environmental heat loads on the crew cabin, the MPS propellant tanks and the vehicle as a whole. The crew cabin insulation is layered composite insulation (LCI) with a black Kapton outer layer. Shell heaters are used to maintain the internal cabin at room temperature. The propellant tanks are nested pairs of LCH4/LOX cryogenic storage tanks surrounded by vacuum jackets (VJs). The VJs have internal multi-layer insulation (MLI) and external LCI with an outer layer of Aluminized Teflon. LCI is installed in the space between the LCH4 and LOX tanks. Broad area cooling tubes are installed under the MLI on the external tank walls with a high degree of thermal contact.

Pumped coolant loops (working fluid water/glycol) collect heat loads from MAV subsystems, located mainly within the crew cabin, and transport them to the external heat exchanger (i.e. evaporator) interface with the loop heat pipe radiator system. The loop heat pipe working fluid $\left(\mathrm{NH}_{3}\right)$ is vaporized in the evaporator and flows to the onboard space radiator/condenser panels, where the working fluid is condensed and heat is rejected to the environment. Condensed working fluid flows back to the evaporator.

Cryocoolers (working fluid $\mathrm{Ne}$ ) are multi-component systems which intercept heat loads penetrating the insulation system surrounding the propellant tanks via the broad area cooling tubing networks on the tank walls. Heat is rejected to the loop heat pipe evaporator, as with the pumped coolant loops. Based on operational constraints, it is assumed that each cryocooler will lift (remove) $100 \mathrm{~W}$ at $90 \mathrm{~K}$. Active cryocoolers will maintain redundant components/units in a standby condition until needed.

The MAV TCS is fully integrated with the Mars Descent Module (MDM) TCS, and the two operate as one subsystem throughout the outbound flight and Mars surface stay until Mars launch and ascent (when the MAV flies independently). The MAV benefits from the afforded cooling and heat rejection load-sharing across the wide range of thermal environments, especially in the Mars surface environment. This approach also allows for the MAV to carry a minimum amount of TCS subsystem hardware, with the majority being left behind on the MDM at Mars launch. Table 7 gives available MAV and MDM cryocooler lift and active radiator area. Table 8 lists the thermal system masses required for heat rejection. These are grouped on the second stage and do not include the propulsionrelated thermal elements that are given above in Tables 3 and 4.

Table 7. MAV and MDM Heat Loads, Cryocooler Lift and Active Radiator Area.

\begin{tabular}{|c|c|c|c|c|}
\hline Mission phase & $\begin{array}{c}\text { Available cryocooler } \\
\text { lift, MAV }(\mathrm{W})\end{array}$ & $\begin{array}{c}\text { Available cryocooler } \\
\text { lift, MDM }(\mathrm{W})\end{array}$ & $\begin{array}{c}\text { Available radiator } \\
\text { area, MAV }\left(\mathrm{m}^{2}\right)\end{array}$ & $\begin{array}{c}\text { Available radiator } \\
\text { area, MDM }\left(\mathrm{m}^{2}\right)\end{array}$ \\
\hline Outbound flight & 100 & $100(300$ standby) & 32 & 29 (stowed) \\
\hline Mars surface stay & 100 & 400 & 32 & 130 (deployed) \\
\hline Mars orbit, MAV only & 100 & - & 32 & - \\
\hline
\end{tabular}


Table 8. Thermal Subsystem Masses.

\begin{tabular}{|c|c|c|c|c|c|}
\hline Item & Qty & $\begin{array}{c}\text { Unit Mass } \\
(\mathrm{kg})\end{array}$ & $\begin{array}{c}\text { Basic Mass } \\
(\mathrm{kg})\end{array}$ & $\begin{array}{c}\text { Growth } \\
(\%)\end{array}$ & $\begin{array}{c}\text { CBE Mass } \\
(\mathrm{kg})\end{array}$ \\
\hline \multicolumn{6}{|c|}{ Dry Mass } \\
\hline Thermal Control & & & 434 & 25 & 542 \\
\hline Active Cooling Loops & 1 & 180 & 180 & 25 & 225 \\
\hline Cabin Shell Heaters & 1 & 10 & 10 & 25 & 13 \\
\hline Radiators/Sublimators & 1 & 108 & 108 & 25 & 134 \\
\hline Cabin External Insulation & 1 & 136 & 136 & 25 & 170 \\
\hline \multicolumn{6}{|c|}{ Non-Propelled Fluids } \\
\hline Coolants, Active Cooling Loops & & & 50 & 25 & 63 \\
\hline
\end{tabular}

During the outbound flight and Mars surface stay, the combined MAV and MDM TCS heat collection/rejection capacity is sufficient to dissipate all MAV environmental and subsystem heat loads. At the time of Mars liftoff, the propellant tanks receive the high heat loads of the Mars surface environment when the cooling and heat rejection resources of the MDM TCS are suddenly unavailable. Due to the expected heat soakback from the tanks' insulation systems, propellant subcooling prior to Mars launch may be required to maintain appropriate propellant conditions after Mars launch.

\section{E. Avionics}

Avionics for the MAV are based on the Altair lunar lander ascent module avionics systems ${ }^{9}$. The Altair lunar ascent module had a very similar mission profile: ascend with 4 crew members and dock to an orbiting spacecraft. Key design components are a distributed command and data handling system using common avionics boxes, guidance, navigation and control systems to enable rendezvous and low impact docking with the orbiting spacecraft. Communications and tracking systems are also included. Table 9 summarizes the masses assumed for the avionics system. Future work will involve designing an avionics system specific to the MAV.

Table 9. Avionics Masses.

\begin{tabular}{|c|c|c|c|c|c|}
\hline Item & Qty & $\begin{array}{c}\text { Unit Mass } \\
(\mathrm{kg})\end{array}$ & $\begin{array}{c}\text { Basic Mass } \\
(\mathrm{kg})\end{array}$ & $\begin{array}{c}\text { Growth } \\
(\%)\end{array}$ & $\begin{array}{c}\text { CBE Mass } \\
(\mathrm{kg})\end{array}$ \\
\hline Avionics & & & 340 & 20 & 407 \\
\hline Command and Data Handling & 1 & 238 & 238 & 20 & 286 \\
\hline Communication and Tracking & 1 & 46 & 46 & 25 & 57 \\
\hline Guidance, Navigation, and Control & 1 & 56 & 56 & 15 & 64 \\
\hline
\end{tabular}

\section{F. ECLS}

Like the avionics system, the life support systems for the Mars Ascent Vehicle are based heavily on the Altair life support systems ${ }^{10}$. Some changes are made to the water system to include additional capability for purification due to the long duration of dormancy prior to crew access on the Martian surface. Additionally, nitrogen and oxygen supplies for cabin atmosphere are increased to allow for a small degree of cabin leakage during the vehicle's long duration of dormancy. The ECLS masses are shown in Table 10.

Table 10. ECLS Masses.

\begin{tabular}{|l|c|c|rr|}
\hline \multicolumn{1}{|c|}{ Item } & $\begin{array}{c}\text { Basic Mass } \\
(\mathrm{kg})\end{array}$ & $\begin{array}{c}\text { Growth } \\
(\%)\end{array}$ & \multicolumn{2}{c|}{$\begin{array}{c}\text { CBE Mass } \\
(\mathrm{kg})\end{array}$} \\
\hline Dry Mass & $\mathbf{2 3 6}$ & $\mathbf{2 6}$ & $\mathbf{2 9 8}$ \\
\hline Non-propelled Fluids & $\mathbf{1 9 6}$ & $\mathbf{0}$ & $\mathbf{1 9 6}$ \\
\hline Nitrogen & 21 & & 0 & 21 \\
\hline Oxygen & 17 & 0 & 17 \\
\hline Water (LCG) & 13 & & 0 & 13 \\
\hline Water (Sublimator) & 109 & & 0 & 109 \\
\hline Water (Potable) & 36 & 0 & 36 \\
\hline
\end{tabular}




\section{G. Human Factors/Cargo}

This section describes the MAV payload (or cargo), which includes the crew, their support equipment and consumables (other than ECLS items), and the returned science samples. The type and quantity of Human Factors equipment needed is a function of a vehicle's crewed duration. Unlike longer-duration vehicles, the MAV's relatively short 2-day operational life allows the omission of many standard crew comfort items, such as a food warmer, potty, and exercise equipment. MAV Human Factors mass is best characterized as being limited to consumables and safety gear.

The MAV consumables include food, hygiene supplies (such as wet-wipes), and crew-worn items such as Maximum Absorbency Garments (MAGs). Potable water and breathing gasses are assumed to be part of the ECLS non-propellant fluids. Food consumption is based on a $1.831 \mathrm{~kg}$ per crew member per day requirement, including food wrappers plus a stowage bag to secure the food.

Safety gear includes personal radiation dosimeters, cabin illumination, a tool kit for contingency operations (such as a jammed hatch mechanism), a clean-up kit, and recumbent seating. For the purpose of this exercise, recumbent seats are assumed to be similar to the Orion project's seats and are by far the single largest Human Factors allocation at $22.7 \mathrm{~kg}$ each. Although MAV ascent

Table 11. Cargo Assumptions.

\begin{tabular}{|l|c|}
\hline \multicolumn{1}{|c|}{ Item (\# items) } & Assumption \\
\hline Crew (4) & $98.5 \mathrm{~kg} /$ person \\
\hline Food + Baggage & $1.831 \mathrm{~kg} /$ person/day $+1.56 \mathrm{~kg}$ \\
\hline Daily Crew Provisions & $0.8825 \mathrm{~kg} /$ person/day \\
\hline Total Mission Provisions & $25 \mathrm{~kg} /$ person $+87.2 \mathrm{~kg}$ \\
\hline Crew Transfer Bags & $30.4 \mathrm{~kg}$ \\
\hline Safety & $39 \mathrm{~kg}$ \\
\hline Recumbent Seats $(4)$ & $22.7 \mathrm{~kg} / \mathrm{seat}$ \\
\hline Umbilical Interfaces $(2)$ & $10.5 \mathrm{~kg} / \mathrm{interface}$ \\
\hline $11 \mathrm{ft}$ Umbilicals $(4)$ & $9.07 \mathrm{~kg} / \mathrm{umbilical}$ \\
\hline IVA LEA Suit $(4)$ & $15.5 \mathrm{~kg} / \mathrm{suit}$ \\
\hline Total MAGs & $2.6 \mathrm{~kg}$ \\
\hline Sample Container $(10)$ & $1.1 \mathrm{~kg} / \mathrm{container}$ \\
\hline Samples & $239 \mathrm{~kg}$ \\
\hline
\end{tabular}

Total Mass: $\quad 1,106 \mathrm{~kg}$

acceleration loads are considered relatively gentle for a healthy crew launching from Earth, recumbent seating protects for two contingency scenarios: early return of deconditioned crew, or an incapacitated crew member. Forward work on these contingencies may offer mass reduction opportunities. All crew and cargo mass assumptions are listed in Table 11.

\section{Design Sensitivities and Variants}

\section{A. Sensitivities to Ascent Flight Time}

Crew consumables (food, water, and oxygen) mass and volume obviously increase as ascent flight time increases, but two additional sensitivities to ascent flight time are noted within Human Factors. Beyond two days it becomes difficult to keep crew inside their space suits. At this point, a crew waste and hygiene compartment (potty) begins to trade favorably for volume and health risk rather than accumulating soiled MAGs in the crew cabin. However, a waste/hygiene compartment comes with a mass and power penalty, plus additional cabin "elbow room" to remove and stow the suits. Beyond eight days in microgravity, the crew will require exercise equipment to maintain physical conditioning, which drives cabin volume and mass for both the exercise equipment and the accessories (workout clothing, harnesses, special shoes, etc.) that may be required. If a larger crew cabin is needed for extended duration hygiene and exercise, there will obviously be structural mass penalties, as well as impact to virtually every other subsystem. For example, a larger cabin diameter will incur mass penalties for everything from thermal insulation to cover the extra cabin surface area, to longer cable runs between equipment.

\section{B. Propulsion Sensitivities}

The current propulsion system design is based heavily on trades performed in 2012 and documented in the Mars Design Reference Architecture 5.0 Addendum $2^{11}$. With the information gained in the latest design, new engine performance sensitivities are evaluated by optimizing trajectories using POST with the new mass information. Below are the results of two such trades. Figure 9 shows the effects of engine thrust on the MAV liftoff mass, while Fig. 10 shows the sensitivity to specific impulse. As expected, the mass decreases as the Isp increases. The thrust per 
engine is slightly higher than optimal, but the higher thrust is tolerated so the same engine can be used on the descent stage, which benefits from the higher performance.

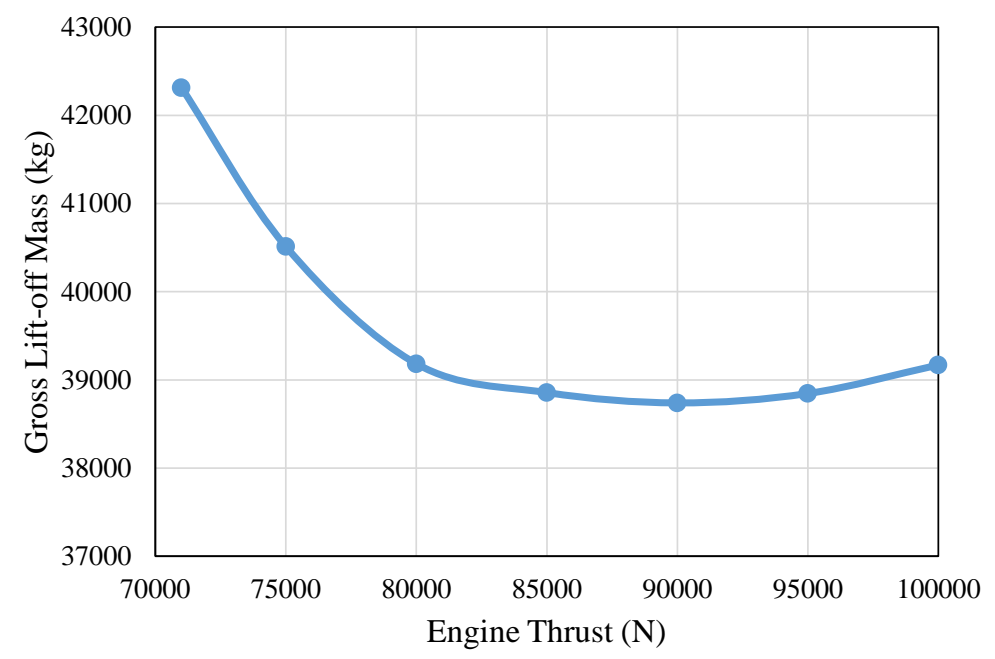

Figure 9. MAV Liftoff Mass vs. Engine Thrust

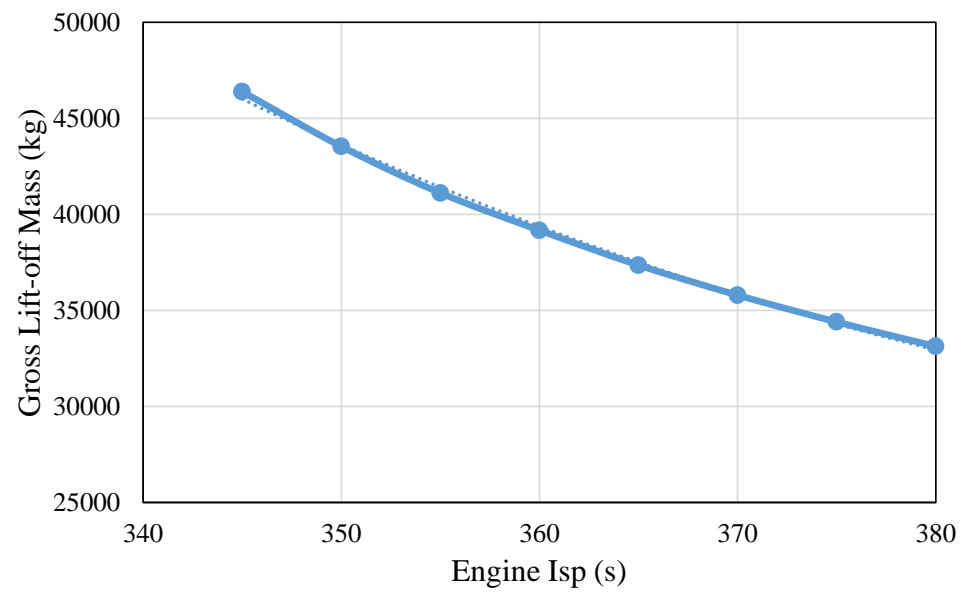

Figure 10. MAV Liftoff Mass vs. Engine Specific Impulse

\section{5 sol MAV}

There are two transportation architectures using SEP and chemical propulsion that are currently being evaluated as part of the Evolvable Mars Campaign. The first, the SEP-Chem Split, relies on purely SEP propulsion to deliver cargo to Mars and uses LOX/methane chemical propulsion stages to deliver crew to Mars and return them to Earth. For this option, the Mars parking orbit is the 1 sol case mentioned above. The second architecture, the SEP Hybrid, uses a combination of SEP and chemical propulsion on the same vehicle. These stages can deliver crew or cargo and may be reusable, returning to lunar vicinity for refueling when the primary mission is complete. The Mars parking orbit for this SEP Hybrid option is significantly larger at $250 \mathrm{~km}$ by $112,500 \mathrm{~km}$ altitude (orbital period of 5 Martian days, or 5 sols).

Using the 1 sol MAV as a reference, estimates were made on how the vehicle mass and functionality might have to change to reach the 5 sol orbit. The $\Delta \mathrm{V}$ needed to reach the higher orbit is the most obvious change (an additional $150 \mathrm{~m} / \mathrm{s}$ ) causing a growth in propellant mass and the associated tank volumes. Launch window availability and flight times are also affected. Because of the significantly larger parking orbit, launch windows may be available only once per week and flight times would typically range from 5-10 days. Options for shortening that flight duration were assessed. More analysis is needed but it appears there may be opportunities to launch and achieve rendezvous in 3 days with only $150 \mathrm{~m} / \mathrm{s}$ more than the 1 sol case. These opportunities are likely to be very 
infrequent. To achieve a 3-day flight time and preserve the option for daily launch windows, an additional $\Delta \mathrm{V}$ capability of nearly $500 \mathrm{~m} / \mathrm{s}$ may be required.

The longer flight duration affects crew consumables and accommodations as discussed in section VI.A above. For the 5 sol MAV, it is assumed that a zero-g Waste Management System (WMS) or potty would need to be included at a mass of about $110 \mathrm{~kg}$. In this design, crew members would still remain in their suits for the majority of the trip because the crew cabin is not large enough to accommodate crew plus suits, which when empty take up almost as much volume as another crew member. The MAV is not currently designed to accommodate a significant cabin atmosphere leakage event. With the crew members suited, they could quickly lower visors and safely continue ascent in an unpressurized cabin.

For the purpose of evaluating the SEP-Hybrid architecture, an assumption of a 3-day ascent and an addition of $150 \mathrm{~m} / \mathrm{s}$ of propulsive capability was assumed. The total impact is $2.3 \mathrm{mt}$ growth in liftoff mass of the MAV and the loss of daily launch opportunities. Greater mass impacts may be realized with further study of rendezvous profiles.

\section{Crew Taxi (1 sol and 5 sol)}

Recent interest in exploration of Mars moon Phobos and Deimos ${ }^{12}$ has sparked interest in using the MAV second stage (with integrated cabin) to transfer crew between the moons and the Earth return vehicle stationed in Mars orbit (either 1 sol or 5 sol orbit). Because this mission may require long loiter in Mars orbit and at least one year loiter near Phobos, the fuel cell power generation system is replaced with a solar array/battery combination, eliminating consumables. Replacing the power system results in a new inert mass of $7.2 \mathrm{t}$.

For a transfer from 1 sol to Phobos and back, the required $\Delta$ Vs are approximately $2000 \mathrm{~m} / \mathrm{s}$ for MPS and the 70 $\mathrm{m} / \mathrm{s}$ for RCS and requires a propellant consumption of $6 \mathrm{t}$, which is well under the allowed maximum of $8.7 \mathrm{t}$. For the $5 \mathrm{sol}$ mission, first the $1 \mathrm{sol} \mathrm{MAV}$ second stage propulsion system is scaled to cover the additional $\Delta \mathrm{V}$ to reach the higher orbit. Then, the power system is replaced (as mentioned above). Finally, the waste management system is upgraded to include the potty, and the crew consumables are increased to allow for a 3-day ascent. This results in an inert mass of $7.6 \mathrm{t}$. The total MPS and RCS $\Delta \mathrm{Vs}$ are nearly identical to the 1 sol case, with different end point values. The resulting 5 sol taxi propellant requirement is $6.3 \mathrm{t}$. This is below the estimated maximum of $8.8 \mathrm{t}$. Recent structural analysis indicates additional changes would be required to support launching from Earth with full LOX propellant tanks since ISRU LOX production would not be available for this mission. These changes will be incorporated in future design iterations of the MAV-based Crew Taxi.

\section{Technologies Required}

One of the main reasons for doing studies of missions so far in the future is to identify necessary capabilities and technologies. This is used to inform technology investment prioritization so that mature technologies exist when vehicle development begins. A number of capabilities will be required to support a human Mars mission architecture. Table 12 identifies enabling technology needs for the Mars Ascent Vehicle. Additional development will be required for supporting mission elements, segments, and operations. 
Table 12. Required Technology Development.

\begin{tabular}{|c|c|c|}
\hline $\begin{array}{l}\text { Topic } \\
\text { Area }\end{array}$ & Category / Technology & Description \\
\hline 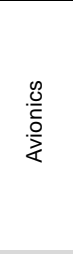 & $\begin{array}{l}\text { Avionics software and Autonomous } \\
\text { Vehicle Systems Management }\end{array}$ & $\begin{array}{l}\text { Management of onboard control, navigation, \& communication systems for rendezvous and proximity ops } \\
\text { - Component-based Software Architecture (e.g., Core Flight System-CFS) } \\
\text { - Wireless Solutions } \\
\text { - Common Modular Hardware Building blocks (e.g., Space Frame) } \\
\text { - In-Space Timing and Navigation for Autonomy } \\
\text { - Target Relative Navigation and Hazard Avoidance }\end{array}$ \\
\hline 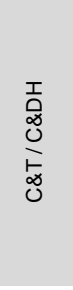 & $\begin{array}{l}\text { Communications and Tracking } \\
\text { (C\&T) / Communications and Data } \\
\text { Handling (C\&DH) }\end{array}$ & $\begin{array}{l}\text { Management of communication, data, and display systems } \\
\text { - High Data Rate Forward Link (Flight) Communications } \\
\text { - High Rate, Adaptive, Internetworked Proximity Communications } \\
\text { - Time Triggered Protocol (TTP/C) } \\
\text { - Optical Communication } \\
\text { - Optical Ranging } \\
\text { - RF Imaging System }\end{array}$ \\
\hline 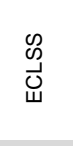 & Life Support & $\begin{array}{l}\text { High reliability, environmental control and life support systems for habitable volumes and EVA } \\
\text { - High pressure oxygen } \\
\text { - CO2 Removal and Advanced Environmental Monitoring } \\
\text { - Universal Waste Management System }\end{array}$ \\
\hline 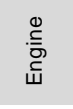 & LOx/LCH4 Cryogenic Propulsion & $\begin{array}{l}\text { Advanced development of integrated primary \& attitude control LOx/LCH4 Engine } \\
\text { - Pump-fed LOXLCH4 Propulsion (common engine development) } \\
\text { - Integrated Pressure-fed LOX/LCH4 Reaction Control Systems }\end{array}$ \\
\hline$\stackrel{\nwarrow}{\square}$ & EVA & $\begin{array}{l}\text { - Advanced space suit } \\
\text { - EVA Tools \& Aids } \\
\text { - Dust mitigation }\end{array}$ \\
\hline 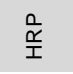 & Biomedical Countermeasures & $\begin{array}{l}\text { - Risk mitigation for GCR and single event exposure } \\
\text { - Long-term exposure to microgravity (support for deconditioned crew affects MAV design) }\end{array}$ \\
\hline $\begin{array}{l}\stackrel{\partial}{\widetilde{N}} \\
\underline{0}\end{array}$ & $\begin{array}{l}\text { LOx In Situ Resource Utilization } \\
\text { (ISRU) } \\
\text { Methane ISRU }\end{array}$ & $\begin{array}{l}\text { Enables a LOX-based economy resulting in a lower outbound vehicle mass and greater payload-carrying } \\
\text { capability } \\
\text { - Extraction of oxygen from CO2 in Martian atmosphere to provide propellant for Mars Ascent Vehicle } \\
\text { (MAV) spacecraft on surface } \\
\text { - NOT currently in baseline: Methane production at Mars supports long-term ISRU Strategy }\end{array}$ \\
\hline$\sum_{0}^{\grave{\alpha}}$ & $\begin{array}{l}\text { Long-life Batteries* } \\
\text { Fuel Cells } \\
\text { Solar Arrays* } \\
\text { Fission Surface Power }\end{array}$ & $\begin{array}{l}\text { - Low cycle, high specific energy for long duration energy storage } \\
\text { - Low mass, high reliability, solid oxide, propellant scavenging of reactants } \\
\text { - Autonomously deployable w/ high strength/stiffness } \\
\text { - High reliability, continuous high power (kW) to support Lander(s) and ISRU reactor, power conversion, } \\
\text { and power conditioning and distribution }\end{array}$ \\
\hline & Structures and Mechanisms & - Lightweight, high-strength, materials, seals and mechanisms, and structural components \\
\hline 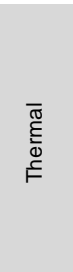 & $\begin{array}{l}\text { Cryogenic Fluid Management and } \\
\text { Storage / Thermal Control Systems }\end{array}$ & $\begin{array}{l}\text { Long-term storage and distribution technologies for cryogens to enable zero boil-off (ZBO) for high } \\
\text { performance cryogenic propulsion systems, surface systems (ISRU), and support power generation and } \\
\text { - } 90 \mathrm{~K} \text { Cryocooler } \\
\text { - Multilayer Layer Insulation } \\
\text { - In Space Cryogenic Liquid Acquisition } \\
\text { - Micro gravity mass gaging } \\
\text { - Thermal control for heat dissipation / heat rejection } \\
\text { - Thermal Protection Systems }\end{array}$ \\
\hline
\end{tabular}

* Only required in MAV-based Crew Taxi variant

${ }^{\dagger}$ Applicable to 5 Sol MAV and 5 Sol Taxi variants

\section{Conclusions}

This work resulted in a significant improvement of our understanding of human Mars ascent vehicle requirements and design options as well as impacts of alternate missions like ascent to a 5 Sol orbit or serving as a crew taxi to and from Mars moons. Trajectory analysis led to a greater understanding of launch windows and performance sensitivities. Aerodynamic analysis resulted in a reduction of early drag estimates and a net savings of propellant mass. Propulsion system design and detailed propellant inventory improved upon earlier estimates and ensures that adequate propellant quantities are allocated. Detailed structures and power system designs replace previous parametric estimates with higher fidelity. Refined thermal analysis led to the addition of significant radiator area which affects RCS placement and placement of other lander payloads around the MAV. Propulsion 
and thermal design efforts have also improved our understanding of required integration with the lander descent stage and ISRU plant. Evaluation of the effects of long duration dormancy led to improvements to ECLS systems, and crew equipment and cargo mass allocations have been reevaluated.

While tremendous progress has been made, we do not know enough yet to reduce the total lander mass from the original estimates which would reduce the challenging performance requirements for our Earth-to-Mars transportation vehicles. Additional work is needed to understand the requirements and mass of other payload elements that are delivered with the MAV such as the crew access tunnel and ISRU plant and to ensure feasibility of the current MAV design. A more thorough evaluation of MAV control systems is desired as well as an evaluation of dynamics of liftoff and staging and a preliminary design for stage separation mechanisms. A review of the avionics systems borrowed from the Altair lander design is needed as well. Continued efforts to refine the MAV design and the sensitivities to Mars architecture options will help to identify the most promising options for future human exploration and the necessary capabilities and technologies to make these missions possible.

\section{Acknowledgments}

Many thanks go out to the members of the MAV design team: Leslie Alexander, Mike Baysinger, Jack Chapman, Tim Collins, Leo Fabisinski, Jeff Gutkowski, Robert Howard, Ashley Korzun, Pat Loyselle, Philip Nerren, David Paddock, Robert Polsgrove, Chris Popp, Imelda Stambaugh, Bill Studak, and John Teter.

\section{References}

${ }^{1}$ Craig, Douglas A., Herrmann, Nicole B., and Troutman, Patrick A. "The Evolvable Mars Campaign - Study Status," IEEE Aerospace Conference, Big Sky, MT, March 7-14, 2015.

2 Percy, Tom, Polsgrove, Tara, McGuire, Melissa, "Combining Solar Electric Propulsion and Chemical Propulsion for Crewed Missions to Mars,” IEEE Aerospace Conference, Big Sky, MT, March 7-14, 2015.

${ }^{3}$ Percy, Thomas K., McGuire, Melissa, Polsgrove, Tara, "In-Space Transportation for NASA's Evolvable Mars Campaign," AIAA Space 2105, Pasadena, CA, 2015.

${ }^{4}$ Merrill, Raymond G., Strange, Nathan, Qu, Min, and Hatten, Nobble, "Mars Conjunction Crewed Missions with a Reusable Hybrid Architectures," IEEE Aerospace Conference, Big Sky, MT, March 7-14, 2015.

${ }^{5}$ Merrill, R.G., Chai, P., Jones, C.A., Komar, D.R., and Qu, M. "An Integrated Hybrid Transportation Architecture for Human Mars Expeditions," AIAA Space 2105, Pasadena, CA, 2015.

${ }^{6}$ Rucker, Michelle "Design Considerations for a Crewed Mars Ascent Vehicle." AIAA SPACE 2015 Conference, Pasadena, CA, 2015.

${ }^{7}$ JSC-65795, Revision: C, "NASA Docking System (NDS) Interface Definitions Document (IDD)," System Architecture and Integration Office Engineering Directorate, National Aeronautics and Space Administration, Lyndon B. Johnson Space Center, Houston, November 2010.

${ }^{8}$ Kos, Larry D., Polsgrove, Tara P., Sostaric, Ronald R., Braden, Ellen M., Sullivan, Jacob J., and Le, Thanh T., "Altair Descent and Ascent Reference Trajectory Design and Initial Dispersion Analyses," AIAA Guidance, Navigation, and Control Conference, Toronto, Ontario, Canada, August 2-5, 2010.

${ }^{9}$ Lee, Allan Y., et al., "Preliminary Design of the Guidance, Navigation, and Control System of The Altair Lunar Lander," AIAA Guidance, Navigation, and Control Conference, Toronto, Ontario Canada, August 2-5, 2010.

${ }^{10}$ Anderson, Molly, Curley, Su, Rotter, Henry, Stambaugh, Imelda, and Yagoda, Evan, "Altair Lander Life Support: Design Analysis Cycles 4 and 5," 41st International Conference on Environmental Systems, Portland, Oregon, July 17-21, 2011.

${ }^{11}$ Drake, Bret G. and Watts, Kevin D., ed., "Human Exploration of Mars Design Reference Architecture 5.0, Addendum 2," NASA/SP-2009-566-ADD2, NASA Johnson Space Center, Houston, Texas, March 2014.

12 Troutman, P., "The Evolvable Mars Campaign - The Moons of Mars as a Destination", Presentation 11th Meeting of the NASA Small Bodies Assessment Group, Washington, DC, July 29-31, 2014. 